\title{
STRUCTURE, FUNCTION, AND MANAGEMENT OF THE BIOLOGICAL SYSTEM FOR SEASONAL SOLAR SALTWORKS
}

\author{
JOSEPH S. DAVIS
}

Department of Botany

University of Florida

Gainesville, Florida 32611-2209

Received: 31/03/00

Accepted: 03/01/01

e-mail: jsd@botany.ufl.edu

\begin{abstract}
The structure and function of communities and biological systems favorable and unfavorable to salt production in the ponds of solar saltworks are described. Favorable systems maintain a diverse biota and power the organisms at levels that enable a saltworks to economically and continuously produce high quality salt at design capacity. Unfavorable systems-the result of disturbances and high concentrations of nutrients in the water-are dominated by a few species that release massive quantities of organic substances, decrease pond surface areas and volumes, and decrease salt quality and quantity. Management practices to obtain and maintain favorable systems under a variety of conditions are reviewed.
\end{abstract}

KEYWORDS: Aphanothece halophytica, brine shrimp, biological management, Dunaliella salina, Halobacterium salinarium, solar salt

\section{INTRODUCTION}

One-third of the worldwide sodium chloride (salt) production (about 200 million tons per year) is manufactured in solar saltworks (marais salants, salinas, saltfields, Salzgärten, solnitzi). A solar saltworks is a series of interconnected concentrating ponds through which seawater flows, evaporates by wind and solar energy, and becomes increasingly salty in successive ponds. In the downstream flow, compounds of low solubility (in respect to sodium chloride) precipitate with calcium carbonate first dropping out near three times, and calcium sulfate (gypsum) first appearing near four times seawater salinity. Shortly before water reaches saturation with sodium chloride, the brine repeatedly flows into crystallizer ponds (crystallizers), where evaporation continues and the liquid above the salt periodically removed until 5-20 cm of salt is deposited on the floors. Then the deposited salt (the crop) is removed (harvested), washed and stockpiled for a time to decrease contaminants, and marketed. In a well functioning and properly managed solar saltworks, this process produces salt whose purity may exceed $99.7 \%$ on a dry basis.

The above physical phenomena of evaporation and precipitation of low- and high-solubility salts are intimately linked to biological processes that occur in every pond of a solar saltworks (Herrmann et al., 1973; Krumbein, 1985). Because brine organisms and the communities they produce are essential to salt production (Davis, 1993), knowledge of the structure, function, and management of the biological system is 
important for saltworks officials. This paper describes the biological system and its function in the concentrating and crystallizing ponds of seasonal saltworks with seawater intake, contrasts selected aspects of favorable and unfavorable biological systems, discusses key organisms, and offers practical management information. Facts reported in this paper have been derived from the author's personal experiences and from data in the learned journals. For ecological, historical, technical, and conservation information on seasonal saltworks the reader is referred to the papers introduced by Busson et al. (1982) and the publications of Britton and Johnson (1987), Petanidou (1977), Sadoul et al. (1998), See (1960) and Ver Planck (1958).

\section{SEASONAL SOLAR SALTWORKS}

Some solar saltworks manufacture sodium chloride continuously throughout the year, but others lie fallow during winters and produce salt only during the summer seasons. Continuously operated saltworks maintain a salinity gradient throughout their ponds during the entire year; they produce salt uninterruptedly (albeit decreased amounts may be harvested in the winters); and their crystallizers maintain a layer of salt (the salt floor) above which the harvestible crop is deposited. These installations are found in dry climates with low annual rainfall (e.g., Brazil, Cabo de Verde, Canary Islands, Caribbean, Columbia, Mexico, Namibia, South Africa, Venezuela, Western Australia).

Seasonal solar saltworks (e.g., shores of Atlantic Europe, the Black Sea and Mediterranean, South China Sea, Yellow Sea, San Francisco Bay), on the other hand, maintain the salinity gradient only during the summer season; they deposit the salt crop on floors of marl or soil, and their last harvest of a salt-producing season is at the end of the summer. After harvest, concentrated brines remaining in the salina are stored in deep ponds whose dilution from winter precipitation will be low. As the next salt-producing season begins, highly diluted water is drained from the shallow ponds, seawater is admitted to certain ponds, and the stored concentrated brines are distributed to appropriate ponds to reestablish the salinity gradient. Seasonal saltworks are found in climates with warm, dry summers, and where 65 to $80 \%$ of the annual rainfall occurs during winter months.

\section{The Brine Biological System}

Attached seaweeds and seagrasses, small animals, and microscopic organisms inevitably develop a biological system composed of planktonic and benthic communities in the ponds of every solar saltworks. The plants, algae, and bacteria with photosynthetic pigments use sunlight energy and inorganic nutrients (e.g., combined nitrogen and phosphate) to manufacture organic matter, but the entire group of organisms consumes and oxidizes these substances. The biological system can help or harm salt production (Davis, 1993; Sammy, 1983).

Biological systems that help salt production 1) develop and maintain planktonic communities consisting of many well represented species that are adapted to narrow salinity ranges, 2) form mat-like benthic communities of many well represented species with appropriate quantities of organic matter on pond floors, ${ }^{1}$ 3) minimize accretion of organic substances and gypsum on pond floors, and 4) produce crops of salt in crystallizers able to support heavy harvest machinery. These biological systems (herein termed favorable or desired systems) are associated with saltworks that continuously and economically produce high quality salt at design capacity. ${ }^{2}$

Biological systems that harm salt production 1) produce communities composed of few species that thrive in a wide range of salinities, 2) form inadequate or excessively developed benthic communities that release damaging quantities of mucilage, and 3) result in low quality salt at less than design capacity. These biological systems (herein termed unfavorable systems) necessitate increased effort and expense to bring the quality of the harvested product to world standards (Davis, 1993).

\footnotetext{
${ }^{1}$ These are defined as mat layers of sufficient thickness and composition to prevent leakage and to sequester nutrients from the overlying water.

${ }^{2}$ A sample of high quality salt (=world standards) has a high percentage of large, solid crystals, low percentage of small, hollow crystals, and low concentrations of contaminants (e.g., $0.03 \%$ calcium, $0.02 \%$ magnesium, $0.11 \%$ sulfate, $0.17 \%$ insoluble substances, and 2 to $3 \%$ water). Crystals of low quality salt are mostly small, or layered pyramids, and hollow, and their contaminants and water content exceed those of the high quality product.
} 
Concentrations of dissolved solids, kinds of organisms (species), and physical phenomena that occur from seawater salinity at the intake to brine saturated with sodium chloride in the crystallizers-all divide a solar saltworks into low, intermediate, and high salinity ponds. Each group of ponds has a highly characteristic biological system. As planktonic organisms adapted to a particular salinity range flow downstream and reach more saline conditions, they die, release their contents, and provide nutrients for the biota in the saltier locations. This succession terminates with the planktonic aerobic red halophilic bacteria in the highly saline ponds and crystallizers.

Because insufficiently developed communitiestypified by clear water, lack of mats on pond floors, and brine leakage-are relatively rare, this condition will not be considered here. Insufficiently developed systems, the consequence of nutrient-poor intake water, can be corrected by appropriate supplements of fertilizers to the ponds (Davis, 1978).

\section{Characteristics of Low Salinity Ponds with Favorable and Unfavorable Biological Systems}

\section{(Bé $3.5^{\circ}$ to Bé $9^{\circ}$; SG 1.025 to SG 1.067) ${ }^{3}$}

Favorable Biological Systems

Of the ponds in the saltworks, those of low salinity occupy the most surface area and volume, contain the largest variety of organisms, and produce the most biomass. More biomass is manufactured than consumed in these ponds.

The planktonic community (algae, bacteria, and protozoa suspended in the water) provides organic nutrients for the entire saltworks, colors the water, aids evaporation, and allows light to reach pond floors. The benthic community (mats on the floors of the ponds) consists of an uppermost layer of microorganisms -similar to those of the plankton- as well as small and microscopic animal life (crustaceans, molluscs, nematodes, ostracods, protozoa); a second layer of bacteria, filamentous and unicellular blue-green algae, and protozoa; and a lowermost layer consisting of bacteria and black organic matter (Thomas and Geisler, 1982). Benthic communities main- tain a diverse biota, and they remove and lock away important quantities of organic substances, combined nitrogen and phosphate from the overlying water.

The mat also moderates leakage through pond floors and maintains desired thickness. Firm adherence of the benthic community to the floors is aided by patches of rooted seagrasses and attached seaweeds. During strong winds, part of the uppermost layer of the mat becomes suspended and imparts additional nutrients and color to the water. Exports from these ponds (organisms, inorganic and organic nutrients) fuel the biota of the downstream systems at desired levels.

\section{Unfavorable Biological Systems}

These result from excessive nutrients in the intake seawater, depths and turbidity of brine that prevent light from reaching the benthic community, and disturbances (high velocity winds, severe wave action, backmixing of brine, brine dilution, breach of dikes). Unfavorable systems develop large populations of plankton composed of a few species which are able to tolerate the entire salinity range. These suspended organisms shade out the seagrasses, the seaweeds, and the benthic community. When the condition remains uncorrected, sections of benthic communities detach from the floors, partially dissolve, and flow downstream. Export of excessive quantities of microorganisms inorganic and organic nutrients from planktonic and damaged benthic communities create unfavorable systems in the downstream ponds.

\section{Characteristics of Intermediate Salinity Ponds with Favorable and Unfavorable \\ Biological Systems}

\section{(Bé $10^{\circ}$ to Bé $19^{\circ}$; SG 1.075 to SG 1.152)}

Favorable Biological Systems

Volume of water, surface area, and variety of organisms are smaller than in the low salinity ponds. More organic matter is consumed than is produced in these ponds.

Imports from the upstream ponds, and microorganisms produced within the intermediate salinity ponds are maintained at desired levels by the resident suspended bacteria and by grazing brine

${ }^{3} \mathrm{SG}=$ specific gravity; Bé $=145-145 /$ specific gravity. 
shrimp (Artemia $)^{4}$, chironomid and brine fly larvae. Appropriate concentrations of nutrients, competition for resources among the many species, and stable salinity gradients throughout the ponds restrain undesirable algae from becoming dominant.

Benthic communities seal ponds against leakage and maintain a diverse biota of well represented organisms in their uppermost layers. Their lowermost layers (bacteria and black organic substances) remain firmly attached to pond floors, maintain desired thickness, and sequester important quantities of organic matter, combined nitrogen, and phosphate from the overlying water. Organisms in the mat are adapted to narrow segments of the salinity range in which they occur.

\section{Unfavorable Biological Systems}

Excessive nutrients imported from upstream, disturbances, and inappropriate management of brine depths and flows result in massive reproduction of organic-releasing algae in the plankton, release of damaging quantities of organic substances and mucilage to the brine, decreased levels of dissolved oxygen, and decreased biodiversity. Complexation of calcium ions with high levels of organic matter (Chave and Suess, 1970; Kitano et al., 1969) causes calcium carbonate (Herrmann et al., 1973) to precipitate at higher than expected salinities, brine turbid with carbonates and gypsum (Sammy, 1989), and decreased evaporation. These phenomena create viscous brine and environments highly unfavorable to Artemia (Kristensen and Hulscher-Emeis, 1972; personal experience), resulting in increased calcium and sulfate concentrations in the harvested salt.

Excessively developed systems are caused by high concentrations of nutrients in the intake water, droppings from large numbers of waterfowl, accumulated organic substances in the ponds, inappropriate saltworks design, insufficient competition among organisms for nutrients (due to dominance of one or more species), fluctuating salini- ties within ponds, and disturbances. Excessively developed benthic communities dominated by organic-releasing algae become gelatinous, trap gases, accrete excessively, and decrease pond surface areas and volumes. If the condition is not corrected, patches of the community detach from the pond floor, float to the surface, partially dissolve, increase the viscosity of the brine, decimate the Artemia population, and contribute damaging quantities of organic substances to all the downstream ponds (Davis, 1993).

\section{Characteristics of High Salinity Ponds with Favorable and Unfavorable Biological Systems (Bé 20 ${ }^{\circ}$ to Bé $25^{\circ}$; SG 1.161 to SG 1.210)}

\section{Favorable Biological Systems}

Of the concentrating circuit, the high salinity ponds have the least surface area and volume, and the smallest variety of organisms. Their planktonic communities are dominated by Halobacterium salinarium (aerobic red halophilic bacteria); Dunaliella salina is present in low concentrations. Nutrients from upstream (mainly living and dead organisms, particulate and dissolved organic matter) power the biota; little to no organic matter is manufactured by photosynthetic organisms in these ponds.

When appropriate quantities of nutrients ${ }^{5}$ reach the ponds, the planktonic Halobacterium salinarium color the brine pink to bright red-hues that aid solar energy absorption and brine evaporation, and through their rapid metabolism maintain organic matter at desired levels (Davis, 2000). The firm gypsum deposit (calcium sulfate) remains attached to pond floors, accretes only slightly over time, is free of adherent mucilage, and covers large areas of the bottoms. A threelayered benthic community blue-green algae uppermost, purple bacteria (Chromatium and Thiocapsa) in the center, and black organic matter lowermost (Caumette et al., 1994) -able to remove and lock away organic and inorganic sub-

\footnotetext{
${ }^{4}$ The essentiality of Artemia (brine shrimp) to salt production lies in the ability of the animals to clear brine of particles up to 50 micrometers dia. (Dobbeleir et al., 1980), to metabolize large amounts of ingested organic matter to carbon dioxide, to deposit wastes in fecal pellets that become incorporated in the benthic community, and to furnish highly suitable food for the Halobacterium salinarium populations in the downstream ponds (Davis, 1980, 1993; Jones et al., 1981).

${ }^{5}$ These are defined as the quantities and quality of organic substances in crystallizers that enable Halobacterium salinarium to maintain their population at several billions per liter, and that keep concentrations of Dunaliella salina low.
} 
stances (Davis and Giordano, 1996)- exists within the gypsum deposit, under the gypsum, and on floor areas without gypsum. Bacteria associated with the deposit erode the lowermost part of the gypsum to a fine sand (Geisler, 1981) part of which may be volatilized (e.g., Grey and Jensen, 1972). These activities decrease the accretion rate of the calcium sulfate and black substances on pond floors. Brine delivered to crystallizers is nearly free of particulate gypsum.

\section{Unfavorable Biological Systems}

Excessive nutrients from the upstream ponds, excessive quantities of imported planktonic Aphanothece halophytica and mucilage from upstream, development of large Dunaliella salina populations, and accumulations of Aphanothece halophytica at the gypsum-water interface result in viscous brine, quantities of suspended organic substances the aerobic halobacteria are unable to control (Davis, 1993), and fast accretion of sediments and gypsum on pond floors and peripheries (e.g., Pavlova et al., 1999). Complexation of calcium salts with the organic matter (Barcelona and Atwood, 1978) and precipitation of gypsum as widely separated microscopic crystals that stay suspended in viscous brine or that become loosely embedded in mucilage on pond floors result in the downstream flow of excessive quantities of dissolved and particulate calcium sulfate to the crystallizers.

\section{Characteristics of Crystallizer Ponds with Favorable and Unfavorable Biological Systems (Bé 25.5 ${ }^{\circ}$ to Bé $30^{\circ}$; SG 1.216 to SG 1.264)}

\section{Favorable Biological Systems}

Appropriate nutrient input from upstream (e.g., sufficient quantities of dead brine shrimp, dissolved and particulate organic substances) allows the resident Halobacterium salinarium population to color the water and maintain the organic content in the brine at desired levels (Davis, 1990). Under these conditions the Dunaliella salina population remains small and contributes insignificant quantities of organic matter to the brine. The salt deposit (crop), crystallizer perimeters, and pond floors remain firm and well able to support heavy equipment. Harvested sodium chloride crystals are mostly solid, and they range from about one $\mathrm{mm}$ to more than three centimeters in the longest dimension. The wash process results in losses of about 12 to $15 \%$, and the residence time of the salt crystals on the stockpile is comparatively short in order to bring the harvested product to world standards.

\section{Unfavorable Biological Systems}

Excessive quantities of organic matter imported from upstream as well as organic release from large populations of Dunaliella salina (Giordano et al., 1994) living in the crystallizers may exceed the ability of Halobacterium salinarium to prevent the substances and algae from accumulating. Organic-rich brine may become viscous, blackened, and depleted of dissolved oxygen, and it decimates the Halobacterium salinarium population. Because organic substances interfere with normal crystal formation (Cooke, 1966; Roux, 1996), the salt deposit in crystallizers becomes soft (mushy) and may not support heavy harvest equipment. Mushy salt first appears at crystallizer perimeters, but the width of the soft salt may increase to include the entire deposit (Davis and Giordano, 1996). Crystals in the harvested crop are mostly layered, hollow, hopper-shaped pyramids; they retain bacteria (Norton and Grant, 1988); and they trap liquid and crystalline contaminants between layers, in cavities, and on their surfaces (Baha Al-Deen and Baha Al-Deen, 1972; Davis, 1993; Dubessy et al., 1983; Geisler, 1981; Masuzawa, 1980). The weight of trapped liquid within salt crystals increases fuel consumption in harvest equipment, and drainage from vehicles that haul brine-laden salt damages roads and dikes. Furthermore, small and hollow crystals decrease the efficiency of the wash process, and they may require complex wash equipment, dual washing, use of caustic compounds, and long residence on the stockpile to prepare the product for market.

\section{PRACTICAL MANAGEMENT INFORMATION}

Except for the few salinas whose design and location complement the physical and biological processes in the ponds to achieve economical and continuous production of high quality salt at design capacity, the biological system in all other saltworks must be managed to achieve these results. Management requires continuously gathered data and appropriately displayed information on the status of the biological and physical 
systems in each set of ponds, as well as constant vigilance and upkeep of the pond system and associated equipment.

\section{Winter Activities}

Slack seasons provide opportunity for maintenance of roads, dikes, and machinery, and preparation of pond floors for the new season (Jakubowsky, 1949; Perthuisot, 1982; Ver Planck, 1958). Retention of intermediate salinity brine in crystallizers to allow growth of an organic layer on the floors (Fürer, 1900; Mannar and Bradley, 1984) as well as application of soft bay mud free of shells to the floors (Ver Planck, 1958)-both facilitate separation of salt from native bottom materials during harvest.

\section{Production Season Activities}

Continuous maintenance of the salinity gradient within each pond and between ponds in narrow and unchanging limits during the production season sustains a maximum diversity of organisms suited to each salinity range and suppresses mucilage-producing organisms adapted to fluctuating ionic concentrations (Coleman and White, 1993; Davis, 1993). Implementation to keep salinity constant at any place in the concentrating ponds can be accomplished by appropriately adjusting flow rates to match evaporation, by placing strategically-located dikes that partially or completely traverse ponds to prevent backmixing and decrease wave fetch, by providing standby pumps at each pump station, by preventing land runoff from entering ponds, and by removing rainwater with decanters (Davis, 1993).

\section{Management of Key Organisms}

\section{Artemia}

By converting much of the massive plankton imported from upstream into their own substance, Artemia in the intermediate salinity ponds provide an important link between the biota of the low and high salinity ponds (Davis, 1990). In many saltworks, the local Artemia strain is self maintaining, sufficiently aggressive to clear the brine, and able to quickly develop functioning populations after the desired salinity gradient has been reestablished. However, reintroduction of
Artemia may be required when numbers of the animals are too small to control the plankton and suspended organic particulates. New introductions are indicated when the population of the local strain remains too small or performs poorly (Geddes and Williams, 1987; Haxby and Tackaert, 1987; Tackaert and Sorgeloos, 1993). Maintenance of Artemia populations able to accomplish activities essential to salt production can be aided by increasing brine depths in the intermediate salinity ponds for greater production of suitable food and by preventing brine temperatures from exceeding $35{ }^{\circ} \mathrm{C}$ (Sorgeloos, 1988), by maintaining the salinity within and between ponds in a narrow and constant range, and by modifying ponds to minimize large accumulations of the animals and cysts in windward corners. Implementation of management practices that allow favorable systems to develop in the low salinity ponds help to provide suitable food and appropriate conditions for brine shrimp in the intermediate and high salinity ponds.

\section{Aphanothece halophytica}

These euryhaline, slime-producing algae grow best in intermediate salinities (Oren, 2000; Margheri et al., 1987), but the organisms survive and continue to release mucilage well into high salinities (Berland et al., 1989; personal experience). Techniques that minimize growth of Aphanothece halophytica include establishment of sufficient numbers of ponds to keep the salinity gradient in each pond narrow, adjustment of depths in low and intermediate salinity ponds to allow light to reach the pond floors and permit nutrient-sequestering benthic communities to develop and function (De Medeiros Rocha and Camara, 1993), use of an «artificial wetland $»^{6}$ to strip nutrients from the intake water (see below), and establishment of functioning Artemia populations.

\section{Dunaliella salina}

Although D. salina reproduce best in intermediate salinities, the organisms continue to divide slowly in the high salinity and crystallizer ponds. When excessively high concentrations of nutrients reach the high salinity and crystallizer ponds,

${ }^{6}$ Du Toit and Campbell (unpublished) 
Dunaliella salina may form populations sufficient to color the brine red-orange and release damaging quantities of organic substances (Giordano et $a l ., 1994)$. Concentrations of $D$. salina can be kept low by management practices that aid maintenance of large Artemia populations in the intermediate salinity ponds and functioning nutrientsequestering benthic communities and stable salinities in the low and intermediate salinity ponds.

\section{Halobacterium salinarium}

Management techniques to obtain high concentrations of these bacteria in the high salinity ponds and crystallizers begin by maintaining favorable biological systems in the low and intermediate salinity ponds. In the highly saline ponds, shallow brine depths (Herrmann et al., 1973; McArthur, 1980) and long residence of brine allow sufficient concentrations of oxygen to diffuse into the brine to maintain high concentrations of Halobacterium salinarium. Because petroleum products are toxic to the bacteria (Ward and Brock, 1978), care must be taken to prevent machinery used in crystallizers from leaking fuel, grease, or hydraulic fluids. Effects of spills can be minimized by quickly removing leaking vehicles and by extracting salt and soil contaminated with petroleum products.

\section{Fabrea salina}

Fluctuating salinities coupled with excessive nutrients in the water may result in germination of dormant cysts which become large populations of Fabrea salina (Gervais, 1969; personal experience). These motile ciliates, too large to be ingested by Artemia, consume suspended organic matter and microorganisms, and they release mucilaginous substances. These events are usually followed by a severe decline of the Artemia population, excessive reproduction of Aphanothece halophytica, and increased export of organic substances to the downstream ponds.

\section{Proactive Management}

\section{Nutrient Removal from the Intake Seawater}

Excessive nutrients in the intake water result in slowly developing problems often unobserved during the tenure of most management officials. An experimental technique in a South African saltworks designed to decrease concentrations of combined nitrogen, phosphorus, and organic substances in the intake water employed an «artificial wetland» through which seawater flows before entering the saltworks. An artificial wetland is a broad, shallow (10-15 cm depth) biofilter area whose rooted plants and microorganisms on the floor develop an efficient nutrient-sequestering community.

\section{Nutrient Removal Within the Ponds}

Nutrients can also be decreased by harvesting fish, seaweeds, oysters, pinaeid shrimp, brine shrimp, and Dunaliella salina (Laubscher and Mackle, 1998). Other measures include addition of ponds to each of the salinity ranges to increase ionic stability, use of dikes that partially traverse ponds to prevent mat destruction by waves and winds, and manipulation of water depths to prevent wading birds from foraging in the ponds (Valesquez, 1992).

\section{Information Gathering}

Information can be obtained to ascertain the health of the biological system and to indicate the approach of certain undesirable situations and allow adjustments before disasters occur. Constant surveillance of dikes, pond floors and depths, gates, weirs, and pumps, along with data routinely gathered by most saltworks (evaporation, concentrations of contaminants in salt, range of crystal sizes in representative salt samples, efficiency of the salt-washing process) appropriately displayed over time can indirectly indicate the health of the biological system. Value of this information can be increased by routinely determining and displaying concentrations of chlorophyll a, combined nitrogen, phosphorus, organic matter, and concentrations of key organisms in the water (e.g., Aphanothece halophytica, Dunaliella salina, Fabrea salina, Halobacterium salinarium). Dominant organisms, particularly diatoms, can be used as indicators of time-integrated water quality in the ponds (Campbell and Davis, 2000). Anecdotal records of usual and unusual biological and physical events can become a valuable supplement for the other information.

\section{Disturbance Management}

Preparation for high velocity winds, prolonged rainfall, and spills of petroleum products will min- 
imize the consequences of these events. Damage to dikes from wave action and winds can be minimized by appropriate armoring (rip-rap), proper orientation of ponds to prevailing winds, and dikes that partially traverse ponds to decrease wave fetch. Preparation of high salinity ponds for expected rainfall can be accomplished by deposition of a layer of salt on the floors; this will prevent the death of red halophilic bacteria. Spills of petroleum products can be decreased by careful inspection and proper maintenance of vehicles used in crystallizers.
Post disturbance management includes use of efficient decanters to remove rainwater above the brine, complete drainage of severely diluted brine, cessation of flows and pumping until the usual salinity gradient becomes reestablished, fast repair of damaged dikes and equipment, and immediate removal of vehicles leaking hydraulic fluids, fuel, and other petroleum products. If the brine shrimp population has been decimated, professional reintroduction of Artemia will be necessary to restore the essential functions of these animals.

\section{REFERENCES}

Baha Al-Deen, B. and Baha Al-Deen, A. (1972), Posible efecto de microalgas en la forma de cristalizacion del cloruro de sodio en la salina de Araya, Boletin del Instituto Oceanografico Universidad de Oriente, 11, 35-38.

Barcelona, M.J. and Atwood, D.K. (1978), Gypspum-organic interactions in natural seawater: effect of organics on precipitation kinetics and crystal morphology, Marine Chemistry, 6, 99-115.

Berland, B., Le Campion, T. and Campos Baeta Neves, M.H. (1989), Interaction de la salinité et de la température sur la morphologie, la croissance et la composition cellulaire d'une Cyanobactérie halotolerante (Aphanothece sp.), Botanica Marina, 32, 317-329.

Britton, R.H. and Johnson, A.R. (1987), An ecological account of a Mediterranean salina: the Salin-de-Giraud, Camargue (S. France), Biological Conservation, 42, 185-230.

Busson, G., Cornée, A., Dulau, N., Fontes, J.C., Geisler, D., Gouleau, D., Jaccard, J., Landry, J.C., Noël, D., Perthuisot, J-P., Pierre, C., Poumot, C., Tétart, J.C., Thomas, J.C., Thomas, M., Trauth, N. and Zaninetti L. (1982), Nature Et Genèse Des Faciès Confines, Données hydrochemiques, biologiques, isotopiques, sedimentologiques et diagénetiqués sur les marais salants de Salin-de-Giraud (Sud de la France), Géologie Méditerranéenne, 9.

Campbell, E.E. and Davis, J.S. (2000), Diatoms as indicators of pond condition in solar saltworks, In: $8^{\text {th }}$ World Salt Symposium, Geertman, R.M. (Ed.), Elsevier, 2, 855-860.

Caumette, P., Matheron, R., Raymond, N. and Relexans, J.-C. (1994), Microbial mats in the hypersaline ponds of Mediterranean salterns (Salin-de-Giraud, France), FEMS Microbial Ecology, 13, 273-286.

Chave, K.E. and Suess, E. (1970), Calcium carbonate saturation in seawater: effects of dissolved organic matter, Limnology and Oceanology, 15, 633-637.

Coleman, M.V. and White, M.A. (1993), The role of biological disturbances in the production of solar salt, Seventh Symposium on Salt, 2, 623-631.

Cooke, E.G. (1966), The effects of additives on the crystal form of sodium chloride, Second Symposium on Salt, 2 , 259-268.

Davis, J.S. (1978), Biological communities of a nutrient-enriched salina, Aquatic Botany, 4, $23-42$.

Davis, J.S. (1980), Experiences with Artemia in solar saltworks, In: The Brine Shrimp Artemia, Ecology, Culturing, Use in Aquaculture, Persoone, G., Sorgeloos, P., Roels, Q. and Jaspers, E. (Eds.), Universa Press, Wetteren, Belgium, 3, 51-55.

Davis, J.S. (1990), Biological management for the production of salt from seawater, In: Introduction to Applied Phycology, Akatsuka, I. (Ed.), SPB Academic Publishing bv, The Hague, 479-488.

Davis, J.S. (1993), Biological management for problem solving and biological concepts for a new generation of solar saltworks, Seventh Symposium on Salt, 1, 611-616.

Davis, J.S. and Giordano, M. (1996), Biological and physical events involved in the origin, effects, and control of organic matter in solar saltworks, International Journal of Salt Lake Research, 4, 335-347.

Davis, J.S. (2000), Ten commandments for biological management of solar saltworks, In: $8^{\text {th }}$ World Salt Symposium, Geertman, R.M. (Ed.), Elsevier, 1, 511-516.

De Medeiros Rocha, R. and Camara, M.R. (1993), Prediction, monitoring and management of detrimental algal blooms on solar salt production in north-east Brazil, Seventh Symposium on Salt, 1, 657-660. 
Dobbeleir, J., Adam, N., Bossuyt, E., Bruggeman, E. and Sorgeloos, P. (1980), New aspects of the use of inert diets for high density culturing of brine shrimp, In: The Brine Shrimp Artemia, Ecology, Culturing, Use In Aquaculture, Persoone, G., Sorgeloos, P., Roels, O. and Jaspers, E. (Eds.), Universa Press, Wetteren, Belgium, 3, 165-174.

Dubessy, J., Geisler, D., Kosztolanyi, C. and Vernet, M. (1983), The determination of sulphate in fluid inclusions using the M.O.L.E. Raman microprobe, Application to a Keuper halite and geochemical consequences, Geochimica et Cosmochimica Acta, 47, 1-10.

Fürer, F.A. (1900), Salzbergbau und Salinenkunde, Vieweg und Sohn, Braunschweig.

Geddes, M.C. and Williams, W.D. (1987), Comments on Artemia introductions and the need for conservation, In: Artemia Research And Its Applications, Sorgeloos, P., Bengtson, D.A., Decleir, W. and Jaspers, E. (Eds.), Universa Press, Wetteren Belgium, 3, 19-26.

Geisler, D. (1981), Gènése et évolution des gypses des marais salants de Salin-de-Giraud (Camargue), Bulletin de Minéralogie, 104, 625-629.

Gervais, C. (1969), Influence de la concentration saline du milieu sur l'éclosion des kystes de Fabrea salina Henneguy (Cilié Hétérotriche), Protistologia, 5, 109-114.

Giordano, M., Davis, J.S. and Bowes, G.B. (1994), Organic carbon release by Dunaliella salina (Chlorophyta) under different growth conditions of $\mathrm{CO}_{2}$, nitrogen, and salinity, Journal of Phycology, 30, 249-257.

Grey, D.C. and Jensen, M.L. (1972), Biogenic sulfur in air pollution, Science, 177, 1099-1100.

Haxby, R.E. and Tackaert, W. (1987), Workshop report: Role of Artemia in solar salt operations, In: Artemia Research and its Applications, Sorgeloos, P., Bengston, D.A., Decleir, W. and Jaspers, E. (Eds.), Universa Press, Wetteren, Belgium, 3, 291-293.

Herrmann, A.G., Knake, D., Schneider, J. and Peters, H. (1973), Geochemistry of modern seawater and brines from salt pans: main components and bromine distribution, Contributions to Mineralogy and Petrology, 40, $1-24$.

Jakubowsky, K. (1949), Seesalzgewinnung an der bulgarischen Schwarzmeerküste, Chimia, 3, 33-38.

Jones, A.G., Ewing, C.M. and Melvin, M.V. (1981), Biotechnology of solar saltfields, Hydrobiologia, 82, $391-406$.

Kristensen, I. and Marian Hulscher-Emeis, T. (1972), Factors influencing Artemia populations in Antillean salines, Studies Fauna Curacao, 39, 87-111.

Krumbein, W.E. (1985), Applied and economic aspects of Sabkha systems-genesis of salt, ore and hydrocarbon deposits and biotechnology, In: Hypersaline Ecosystems The Gavish Sabkha, Friedman, G.M. and Krumbein, W.E. (Eds.), Springer Verlag, Berlin, 426-436.

Laubscher, R.K. and Mackle, D.E. (1998), The improvement of soda ash and salt quality through biological remediation, Metallurgical Symposium of AMCOAL, AAC, AMZIM, AMPLATS, MINORCO, Johannesburg, South Africa, July 29-31.

Mannar, M.G.V. and Bradley, H.L. (1984), Guidelines for the establishment of solar salt facilities from seawater, underground brines and salted lakes, United Nations Industrial Development Organization, UNIDO/IS.330/Rev.1.

Margheri, M.C., Tredici, M.R., Barsanti, L. and Balloni, W. (1987), The photosynthetic community of the Trapani saline lagoons: an alternative option for the exploitation of an extreme environment, Annals of Microbiology, 37, 203-215.

Masuzawa, T. (1980), Impurities contained inside the crystals of solar and vacuum evaporated salts, Fifth International Symposium on Salt, 2, 463-473.

McArthur, J.N. (1980), An approach to process and quality control relevant to solar salt field operations in the northwest of Western Australia, Fifth International Symposium on Salt, 2, 325-334.

Norton, C.F. and Grant, W.D. (1988) Survival of halobacteria within fluid inclusions in salt crystals, Journal of General Microbiology, 134, 1365-1373.

Oren, A. (2000), Salts and brines, In: The Ecology of Cyanobacteria, Whitton, B.A. and Potts, M. (Eds.), Kluwer Academic Publishers, Dordrecht, 281-306.

Pavlova, P., Markova, K., Tanev, S. and Davis, J.S. (1999), Observations on a solar saltworks near Burgas, Bulgaria, International Journal of Salt Lake Research, 5, 1-12.

Perthuisot, J-P. (1982), Introduction général a l'étude des marais salants de Salin-de-Giraud (Sud de la France): le cadre géographique et le milieu, Géologie Méditerranéenne, 9, 309-327.

Petanidou, T. (1977), Salt. Salt In European History And Civilisation, Hellenic Saltworks, S.A., Athens, Greece. 
Roux, J.M. (1996), Production of polysaccharide slime by microbial mats in the hypersaline environment of a Western Australia solar saltfield, International Journal of Salt Lake Research, 5, 103-130.

Sadoul, N., Walmsley, J. and Charpentier, B. (1998), Salinas and Nature Conservation, Conservation of Mediterranean Wetlands, No. 9, Tour du Valat, Arles, 96.

Sammy, N. (1983), Biological systems in north-western Australian solar saltfields, Sixth Symposium on Salt, 1, 207215.

See, D.S. (1960), Solar salt, In: Sodium Chloride: The Production and Properties of Brine, Kaufmann, D.W. (Ed.), American Chemical Society Monograph Series, Reinhold, New York, 96-108.

Sorgeloos, P. (1988), Brine shrimp Artemia in coastal saltworks:-hydrobiological key to improved salt productioninexpensive source of food for vertically integrated aquaculture, In: Proceedings of the International Meeting «Saltworks Conversion For Aquaculture», D’Amelio, V. and Santielli, S. (Eds.), Trapani, 1986, 133-141.

Tackaert, W. and Sorgeloos, P. (1993), The use of brine shrimp Artemia in biological management of solar saltworks, Seventh Symposium on Salt, I, 617-622.

Thomas, J-C. and Geisler, D. (1982), Peuplements benthiques á Cyanophycées des marais salants de Salin-deGiraud (Sud de la France), Géologie Méditerranéenne, 9, 391-411.

Valesquez, C.R. (1992), Managing artificial saltpans as a waterbird habitat: species' responses to water depth manipulation, Colonial Waterbirds, 15, 43-55.

Ver Planck, W.E. (1958), Salt in California, Calif. Div. Mines Bull., 175, 168, San Francisco.

Ward, D.M. and Brock, T.D. (1978), Hydrocarbon biodegradation in hypersaline environments, Applied and Environmental Microbiology, 35, 353-359. 